Doi: HTTPS://DOI.ORG/10.23910/IJBSM/2017.8.3.1781

\title{
Increasing Wheat Productivity under Variable and Changing Climatic Conditions in West Bengal, India
}

\author{
A. Mukherjee ${ }^{182^{*}}$, A. K. S. Huda ${ }^{1}$, T. L. Thentu ${ }^{3}$ and S. Banerjee ${ }^{2}$ \\ ${ }^{1}$ School of Science and Health, Western Sydney University, Hawkesbury Campus, Locked Bag 1797, \\ Penrith, NSW (27 51), Australia \\ ${ }^{2}$ AICRP on Agrometeorology, Directorate of Research, ${ }^{3}$ Dept. of Agronomy, Bidhan Chandra Krishi Viswavidyalaya, \\ West Bengal (741 235), India
}

\section{Corresponding Author}

A. Mukherjee

e-mail: asismukherjee@gmail.com

\author{
Article History \\ Manuscript No. AR781 \\ Received in $15^{\text {th }}$ January, 2017 \\ Received in revised form $28^{\text {th }}$ May, 2017 \\ Accepted in final form $6^{\text {th }}$ June, 2017
}

\begin{abstract}
Wheat is the second important cereal crop after rice in West Bengal. However, its area of cultivation and production remain almost stagnant in recent years due to lower productivity of the crop. Inter seasonal climatic variability is one of the most important reasons behind it. Thus, there is a need to find out suitable management options against such climatic variability, to boost up the productivity. In this study DSSAT 4.5 model was used to simulate the potential yield of wheat for Nadia district for 30 years (1982 to 2011). The long term district wheat yield was also collected for its comparison. The attainable yield with proper agronomic management practices was collected from research experiment conducted at Bidhan Chndra Krishi Viswavidyalaya, for yield gap analysis. Wheat yield was also simulated under five number of irrigation treatments. Result revealed that the potential yield ranges from 5101 to $10128 \mathrm{~kg} \mathrm{ha}^{-1}$ with an average of $8458 \mathrm{~kg}$ $\mathrm{ha}^{-1}$. The average yield produced in research field was $4151 \mathrm{~kg} \mathrm{ha}^{-1}$ and long term average actual district yield was $2316 \mathrm{~kg}^{-1}$. Thus, there is ample scope to reduce the yield gap by around $80 \%$ to reach the attainable (research) yield, only through optimization of different crop management techniques. The result of the irrigation experiment showed that wheat yield increased with increase in number of irrigations. But exceptionally, three number of irrigations produced less yield than that of two numbers of irrigation due to water stress in critical crop growth period.
\end{abstract}

Keywords: wheat, climatic variability, Irrigation, DSSAT

\section{Introduction}

Rice and wheat are two major food crops in India in general and West Bengal (WB) in particular. Therefore, emphasis should be given on improving and sustaining the productivity of these crops towards food security of this state (Sarkar et al., 2013). After 'Green Revolution' higher productivity hence higher profitability leads towards higher area expansion under wheat crop in different district under WB up to the end of 1980s (Pal and Mukhopadhyay, 1980), follo wed by drastic reduction of area during $90 \mathrm{~s}^{\prime}$ and remained almost stable during recent year (Economic review, 2011-12). But overall productivity of the wheat crop increased gradually with some inter-year variability due to weather fluctuation. Temperature is one of the important weather elements that regulate the growth and yield of many crops (Kurek et al., 2007). High temperature stress is an important yield limiting factor in wheat in most of the wheat growing areas (Prasad et al., 2008). In India studies have also shown a trend for increasing air temperature (Sing and Sontakke, 2002). The rainfall amount in
October and November month has shown an increasing trend during 1990-2000 compared to earlier years (Mukherjee and Banerjee, 2009), thus there is a chance of late sowing of winter wheat because of delay in land preparation. On the other hand, share of irrigation to agriculture is diminishing very quickly. Uneven distribution of rainfall and extreme events aggravated the situation. The biggest threat to sustain the rice-wheat productivity in south Asia is water shortage during critical crop growth stages (Subhas and Mohan, 2012). Thus, weather abnormality, untimely sowing, lack of irrigation and low fertilizer use is becoming the major constraints for wheat cultivation in WB situation.

\section{Materials and Methods}

\subsection{Study area}

The study was conducted in Nadia district, which falls under New Alluvial Zone of West Bengal and characterised by 1400 $\mathrm{mm}$ annual rainfall with 31.9 and $20.4{ }^{\circ} \mathrm{C}$ average annual maximum and minimum temperature. Wheat growing season 
extended from middle of November to end of April month.

\subsection{Concept and calculation of yield Gap}

The yield gap is defined as the difference between the yield under optimum management (generally under research field) and the average yield achieved by farmers (Editorial, Field Crop Research 2013). It is a powerful method of understanding the biophysical opportunities to meet the projected increase in demand for agricultural products and to support decision making on research, policies and development. During last decades the yield has become almost stagnant and there are large gaps between potential yield, research yield (attainable) and farmers' (district) yield (Ladha et al., 2003). The difference may be caused by different factors which are not transferable, such as environmental condition and optimum management practices adopted in research field.

The major portion of farming community in WB is marginal. It is very difficult to them to follow optimum crop management practices (e.g. sowing time, irrigation and fertilizer amount and application timing, other agronomic managements) due to poor availability of infrastructural facility and resources. Progressive farmers can produce yield at attainable level by maintaining recommended package and practices. District yield is calculated considering a large number of farmers (small, marginal and progressive) productivity of particular crops. Thus, there is always a gap between research yield and farmers' yield.

The Decision Support System for Agrotechnology Transfer (DSSAT 4.5) includes the Cropping System Model (CSM)-CERESWheat model, which can be used to simulate the growth and development of rain-fed and irrigated wheat worldwide (Jones et al., 2003). In this study DSSAT 4.5 model was used to simulate the potential yield of wheat for Nadia district for 30 years (1982 to 2011). The long term (1982 to 2011) actual wheat yield data (average yield from farmers'field) for Nadia district was collected from the Evaluation Wing, Govt. of WB.

\subsection{Simulation under different water regimes}

Wheat yield was simulated under different number of irrigation treatments through CERES-Wheat crop model in the DSSAT 4.5 platform. The variety was PBW-343. The genetic coefficient of this variety was collected from BCKV Annual Progress Report (2014-15) of FASAL project, Kalyani. In this virtual experiment five $(1,2,3,4,5)$ number irrigations were allotted in $T_{1}$ to $T_{5}$ treatment respectively. The depth of each irrigation was $30 \mathrm{~mm}$. Irrigation was applied as per Table 1.

\section{Results and Discussion}

\subsection{Yield gap and actual trend of wheat yield}

The potential yield ranges from 5101 to $10128 \mathrm{Kg} \mathrm{ha}^{-1}$ with an average of $8458 \mathrm{Kg} \mathrm{ha}^{-1}$ (Figure 1). A sudden decline of potential yield during 2004 may be associated with a high minimum temperature $\left(25.3^{\circ} \mathrm{C}\right)$ at grain filling stage, compared to previous year $\left(21.9^{\circ} \mathrm{C}\right)$.

\begin{tabular}{|c|c|c|c|c|c|c|}
\hline \multirow[t]{2}{*}{ Treatments } & \multirow{2}{*}{$\begin{array}{l}\text { No. of ir- } \\
\text { rigation }\end{array}$} & \multicolumn{5}{|c|}{ No. of irrigation } \\
\hline & & 20 & 35 & 55 & 75 & 95 \\
\hline $\mathrm{T}_{1}$ & 1 & & V & & & \\
\hline $\mathrm{T}_{2}$ & 2 & & V & & 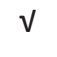 & \\
\hline $\mathrm{T}_{3}$ & 3 & $\mathrm{~V}$ & $\mathrm{~V}$ & & & $\mathrm{~V}$ \\
\hline $\mathrm{T}_{4}$ & 4 & V & V & 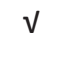 & & v \\
\hline $\mathrm{T}_{5}$ & 5 & $\mathrm{~V}$ & $\mathrm{~V}$ & $\mathrm{~V}$ & $\mathrm{~V}$ & $\mathrm{~V}$ \\
\hline
\end{tabular}

The yield of wheat from a research experiment conducted at

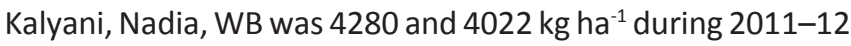
and 2012-13 respectively (Lalmalsawmi, 2013). The average yield (4151 kg ha-1) of this experimentation was considered as the average research yield (Figure 1) of the Nadia district. During 1983, the actual yield was $3159 \mathrm{~kg} \mathrm{ha}^{-1}$, which declined gradually with years and the average actual yield remained as 2488,2140 and $2331 \mathrm{Kg} \mathrm{ha}^{-1}$ respectively during 1980-89,

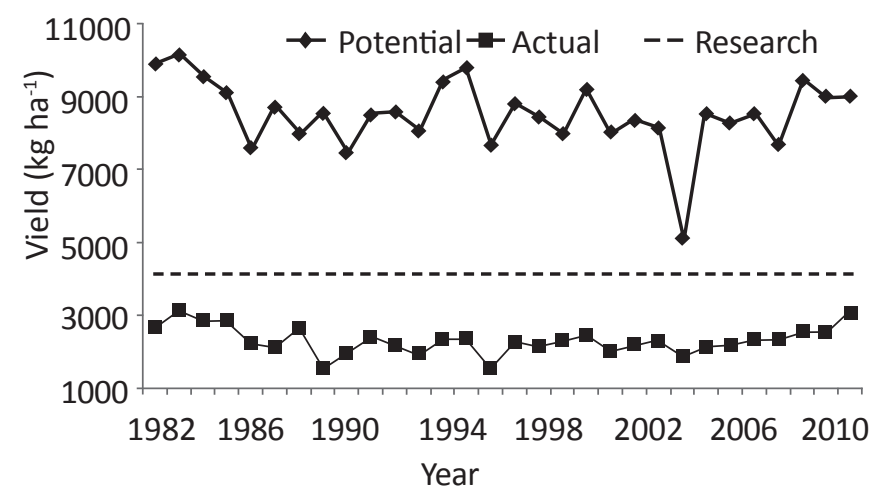

Figure 1: Potential, Research and Actual yield of wheat in Nadia district, WB, India

1990-99 and 2000-2009. A steep increase in actual yield during 2011 is associated with prolonged winter season. Thus, there is an ample scope to increase the actual yield by $80 \%$ to reach the attainable yield, only through optimization of different crop management techniques.

\subsection{Bridging the yield gap considering temperature constraint}

Major constraints to wheat grain yield include high temperatures during grain filling (Andarzian et al., 2008). Thus proper time of sowing is needed to coincide the sensitive stages of the crop to optimum temperature level. Analysis of long term temperature data along with research experimentations can be used to fix the optimum time of sowing. The optimum time of sowing of wheat in WB condition is $3^{\text {rd }}$ week of November (Anonymous, 2012) under irrigated condition and $25^{\text {th }}$ October to $10^{\text {th }}$ November under rain-fed condition.

Parya (2009) observed in the Research Farm of Bidhan Chandra Krishi Viswavidyalaya (BCKV), Jaguli, Nadia, that $18^{\text {th }}$ November sown wheat crop produced the highest yield 
(Table 2) due to superiority of yield attributing characters over other dates of sowing. Increase in maximum and minimum temperature $\left(1.88\right.$ and $\left.1.36^{\circ} \mathrm{C}\right)$ during the post flowering stages under delayed sowing might have reduced the duration of grain filling period which led to reduction in yield. On an average $1^{\text {st }}$ week of December sown crop produced $6.5 \%$ less yield. However, 15 days more delay increase the reduction

Table 2: Effect of dates of sowing on yield $\left(\mathrm{kg} \mathrm{ha}^{-1}\right)$ of wheat cultivars (average of 3 years, 2005-08)

\begin{tabular}{lccc}
\hline Varieties & \multicolumn{3}{c}{ Dates of sowing } \\
\cline { 2 - 4 } & $18^{\text {th }}$ November & $3^{\text {rd }}$ December & $18^{\text {th }}$ December \\
\hline PBW343 & 2730 & 2680 & 1840 \\
HD2733 & 2850 & 2890 & 2410 \\
HW2045 & 2530 & 2380 & 1840 \\
PBW533 & 3540 & 3060 & 2610 \\
K9107 & 3780 & 3400 & 2630 \\
Mean & 3090 & 2890 & 2270 \\
\hline
\end{tabular}

by $26.5 \%$. Similarly in BCKV Research Farm, Gayespur, Nadia, Thentu (2016) recorded maximum wheat yield when sowing was done during $3^{\text {rd }}$ week of November and with delay in sowing (up to 10 December) yield reduced to the tune of 3.2 to $5.3 \%$ (Figure 2). The reduction was $9 \%$ when the crop was sown on $20^{\text {th }}$ December.

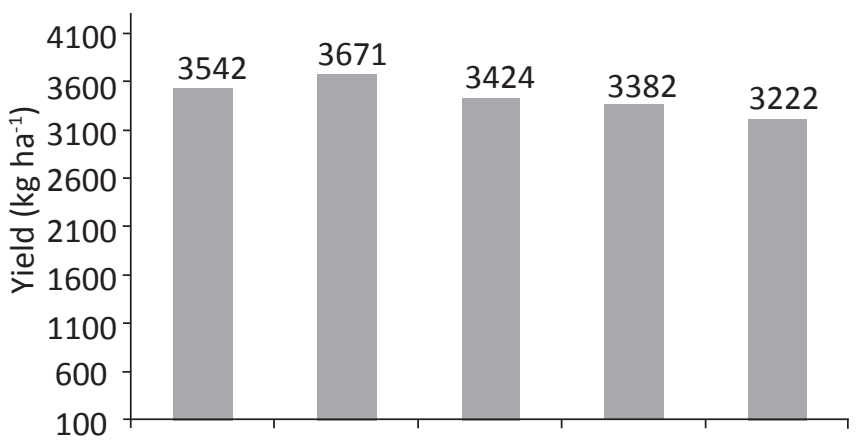

10 Nov 1420 Nov 1430 Nov 1410 Dec 1420 Dec 14

Date of sowing

Figure 2: Impact of date of sowing on yield of wheat in Nadia district, WB, India

\subsection{Irrigation management for yield improvement}

Wheat is a highly water sensitive crop. Water stress reduces the crop yield to different scale depending on the stage(s) of water stress. Water deficit during stem elongation and heading stage resulted significant decrease in yield. Thus, irrigation could be skipped during milking stage to minimize the yield loss (Tari, 2016). After starting with sufficient presowing soil moisture level, a single irrigation of $60 \mathrm{~mm}$ of water at stem elongation stage can achieve high water use efficiency with only $5 \%$ yield reduction from no-water stress treatment (Xu et al., 2016). Lalmalsawmi (2013), in New Alluvial Zone of WB pointed out that, according to water sensitivity the growth stages of wheat are in the order: Flowering>Maximum Tillering $>$ CRI>Milking.

The result of the modelling experiment showed that wheat yield increased with increase in number of irrigations (Figure 3). Exceptionally $T_{3}$ (3 numbers of irrigation) produced $2.6 \%$ less yield compared to $T_{2}$ ( 2 numbers of irrigation). Model output showed that the crop under $\mathrm{T}_{3}$ exposed to water stress (0.29) during end of ear growth (Table 3), which might be

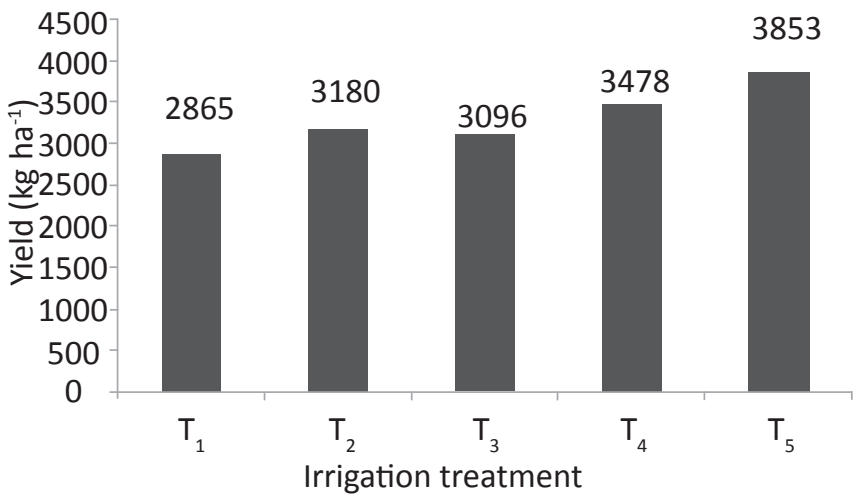

Figure 3: Variation of wheat yield under different irrigation treatments, Kalyani, Nadia, WB, India

Table 3: Water stress (0-1 scale, where 1=maximum stress) in different growth stages of the crop

\begin{tabular}{lccccc}
\hline \multirow{2}{*}{ Stage } & \multicolumn{5}{c}{ No. of irrigation } \\
\cline { 2 - 6 } & One & Two & Three & Four & Five \\
\hline End EAR growth & 0.47 & & 0.29 & & \\
Beginning of grain & 0.74 & 0.58 & 0.51 & 0.35 & 0.04 \\
filling & & & & & \\
End of grain filling & 0.63 & 0.74 & 0.63 & 0.63 & 0.60 \\
\hline
\end{tabular}

possible reason for getting low yield compare to $T_{2}$ irrigation treatment. Thus, under limited water resource proper timing of irrigation plays a vital role. Although the highest yield was obtained under $T_{5}$, but the crop under this treatment also faced water stress during later part of grain filling period. Depth of irrigation should be considered along with the time of irrigation.

\subsection{Dissemination of the weather based crop management strategies}

India Meteorological Department in collaboration with different State Agricultural Universities and Indian Council of Agricultural Research Institutes, is providing weather based agro-advisories to the farming community directly through mobile sms, Krishi Vigyan Kendra, Block office, print and electronic media. Integration of crop management strategies under variable and changing climatic situation, generated through crop growth simulation modelling, with existing advisory will go long way to improve wheat productivity. 


\section{Conclusion}

Flowering and grain filling stages of wheat are highly sensitive to temperature variability and water stress. Agro-climatic analysis assists in screening of suitable wheat growing locations. Crop growth simulation models are effective tools to find out optimum crop management practices. Information generated through agro-climatic and modelling research incorporated in the existing agro-met advisory bulletin will help improve the decision making process of the farming community.

\section{Acknowledgement}

Thankful to Department of Education and Training, Govt. of Australia, for providing 'Endeavour Research Fellowship'-2016 to Dr Asis Mukherjee to carry out his Post-Doctoral research programme. This manuscript is a part of his research programme

\section{References}

Andarzian, B., Bakhshandeh, A.M., Bannayan, M., Emam, Y., Fathi, G., Alami, S., 2008. Wheat Pot: a simple model for spring wheat Yp using monthly weather data. Biosyst. Eng 99, 487-495.

Anonymous, 2012. Annual progress report-2012. All India Coordinated Research project on wheat and barley, BCKV, Kalyani, Nadia. WB, India

Economic Review 2011-12. Govt. of West Bengal, 70.

Editorial, 2013. Yield gap analysis-Rationale, methods and applications-Introduction to the Special Issue. Field Crops Research 143, 1-3.

Jones, J.W., Hoogenboom , G., Porter, C.H., Boote, K.J., Batchelor, W.D., Hunt, L.A., Wilkens, P.W., Singh, U., Gijsman, A.J., Ritchie, J.T., 2003. The DSSAT cropping system model. Europ. J. Agronomy 18, 235-265.

Kurek, I., Chang, T.K., Bertain, S.M., Madrigal, A., LIU, L., Lassner, M.W., Zhu, G., 2007. Enhanced thermo-stability of Arabidopsis Rubisco activase improves photosynthesis and growth rates under moderate heat stress. The Plant Cell 19, 3230-3241.

Ladha, J.K., Pathak, H., Tirol-Padre, A., Dawe, D., Gupta, R.K., 2003. Productivity trends in intensive rice wheat cropping systems in Asia. In: Improving the Productivity and Sustainability of Rice-Wheat Systems: Issues and Impacts. ASA Special Publication 65, 45-76.

Lalmalsawmi., 2013. Impact of irrigation regimes on actual evapotranspiration pattern of wheat grown under varying climatic conditions (M.Sc. Thesis). Accessed from the Library Bidhan Chandra KrishiViswavidyalaya, Mohanpur, Nadia, WB, India.

Mukherjee, A., Banerjee, S., 2009. Rainfall and temperature trend analysis in the Red and Lateritic zone of West Bengal. Journal of Agrometeorlogyll (2), 196-200.

Pal, A., Mukhopadhyay, A., 1980. Factors behind Expansion of Wheat Area in West Bengal. Social Scientist, 8 (9), 25-35.

Parya, M., 2009. Studies on the variation in physical environment and its effect on the growth and yield of wheat cultivars (Triticum aestivum L.) under different dates of sowing (Ph.D. thesis). Accessed from the Library Bidhan Chandra Krishi Viswavidyalaya, Mohanpur, Nadia, WB, India.

Prasad, P.V.V., Pisipati, S.R., Ristic, Z., Bukovnik, U., Fritz, A.K., 2008. Impact of night time temperature on physiology and growth of spring wheat. Crop Science 48, 2372-2380.

Sarkar, D., Vivekananda Datta, V., Chattopadhya, K.S., 2013. Assessment of Pre and Post Harvest Losses in Rice and Wheat in West Bengal. Report on Study No.172, AgroEconomic Research Centre, Visva-Bharati, Santiniketan, 6.

Singh, N., Sontakke, N.A., 2002. On climatic fluctuations and environmental changes of the Indo-Gangetic plains, India. Climatic Change 52, 287-313.

Subash, N., Mohan, H.S.R., 2012. Evaluation of the impact of climatic trends and variability in rice-wheat system productivity using cropping system model DSSAT over Indo-Gangetic plains of India. Agricultural and Forest Meteorology 164, 71-81

Tari, A.F., 2016. The effects of different deficit irrigation strategies on yield, quality, and water-use efficiencies of wheat under semi-arid conditions. Agricultural Water Management 167, 1-10.

Thentu, T.L., 2016. Evaluation of wheat response to irrigation and fertilizer in West Bengal using field experiments and crop simulation modelling (Ph.D. Thesis). Accessed from the Library Bidhan Chandra Krishi Viswavidyalaya, Mohanpur, Nadia, WB, India.

Xu, C., Tao, H., Tian, B., Gao, Y., Ren, J., Wang, P., 2016. Limited-irrigation improves water use efficiency and soil reservoir capacity through regulating root and canopy growth of winter wheat. Field Crop Research 196, 268-275. 